\title{
PENYELENGGARAAN SISTEM INFORMASI HUKUM PERUSAHAAN PADA BADAN USAHA BANK DALAM PELAKSANAAN GOOD CORPORATE GOVERNANCE
}

\author{
Oleh : \\ I Gusti Agung Eka Pertiwi'
}

\begin{abstract}
Good Corporate Governance is the definitive system to regulate and control the company to create value-added to all stakeholders. The concept can be interpreted of Good Governance in Indonesia. There are two things that are emphasized in this concept. First, the importance of the right of shareholders to obtain information correctly (accurately) and timely. Second, the company's obligation to make disclosure is accurate, timely and trasnparan to all information of corporate performance, ownership and stakeholder. This type of research is a kind of juridical empirical research. This study on the effectiveness of the law, namely Legal Information Systems Company On Enterprise Bank in Implementing Good Corporate Governance. This study is limited to the legal aspects of good corporate governance of banking, in particular systems company policy, in particular the company's decision-making system, the implementation of the decision making proces accountable, fast, and accurate, which determines the performance of bank corporate governance. Good Corporate Governance provisions have not been able to support the banking corporate governance, as expected, especially in terms of decision-making performance. Becausethe unavailability of adequate Legal Information System whichcan be used as abasis to organize the decision-making process that is fast and accurate. Slowness and hesitation in making decisions on some banks are generally determined by the availability of Legal Information Systems Company which is a data bank on bank policies that have been established.
\end{abstract}

Keywords: Banking, Good Corporate Governance, Legal Information Systems Company.

\section{PENDAHULUAN}

\section{I.1. Latar Belakang}

Seiring berkembangnya perekonomian di Indonesia melalui bisnis perbankan, mendorong para pelaku bisnis perbankan untuk meningkatkan daya saing usahanya melalui penerapan Good Corporate Governance (selanjutnya disebut GCG). GCG merupakan suatu prinsip tata kelola perusahaan yang baik sebagaimana tertuang

Mahasiswa Program Magister Universitas Udayana, Denpasar, Bali. Alamat, Jl. By Pass Ngurah Rai No. 61 Kedonganan, Kuta, Badung, e-mail: gekcha31@ gmail.com. dalam Peraturan Bank Indonesia (PBI) No. 8/4/PBI/2006 tentang Pelaksanaan GCG bagi bank umum yang di sebagaimana diubah menjadi PBI Nomor 8/14/PBI/2006. Pentingnya GCG bagi bank dalam rangka sebagai penghimpun dana masyarakat yakni; dapat meningkatkan nilai perusahaan, dapat meningkatkan daya saing perusahaan, membangun corporate image/ citra positif, serta dalam jangka panjang dapat menjaga kelangsungan hidup perusahaan.

Bank sebagai lembaga penyalur keuangan pada masyarakat, bank juga sebagai media perantara pihak-pihak yang 
memiliki kelebihan dana dengan pihakpihak yang kekurangan/ yang membutuhkan dana. $^{2}$ Di Indonesia, Bank memiliki misi dan fungsi sebagai agen pembangunan, yaitu sebagai lembaga yang bertujuan menunjang pelaksanaan pembanguanan nasional dalam rangka meningkatkan pemerataan, pertumbuhan ekonomi dan stabilitas nasional kearah peningkatan kesejahteraan masyarakat.

Bank umum adalah bank yang melakukan kegiatan perbankan secara konvensional maupun syariah sebagaimana penjelasan dalam PBI. ${ }^{3}$ Dalam mempraktikkan kaidah-kaidah GCG, perusahaanprusahaan dianjurkan membuat suatu kode etik perusahaan yang pada dasarnya memuat nilai-nilai etika bisnis.

Adanya rambu etika bisnis bertujuan agar terciptanya praktik bisnis yang beretika. Etika bisnis merupakan seperangkat kesepakatan umum yang mengatur relasi antar pelaku bisnis dan antar pelaku bisnis dengan masyarakat, agar hubungan tersebut berjalan dengan baik dan fair. ${ }^{4}$ Etika bisnis kemudian dituangkan dalam bentuk tertulis, dan akhirnya melahirkan kebijakan yang berupa: undang-undang, keppres, peraturan pemerintah, dan sebagainya yang mengatur bagaimana melakukan bisnis yang benar dan sah secara hukum. GCGdalam perbankan, yaitu menciptakan nilai tambah bagi semua pihak yang berkepentingan (stakeholders)

Neni Sri Imaniyanti, 2010, Pengantar Hukum Perbankan Indonesia, Refika Aditama, Bandung, hlm.13.

3 Redo Harina Hutama, 2013,Good Corporate Governance Sebagai Salah Satu Faktor Penilaian Tingkat Kesehatan Bank Umum, Private Law: Vol. 03 Nov. 2013 -Maret 2014. No. 23., Surakarta.

4 Hendrik Budi Untung, 2008, Corporate Social Responsibility, Sinar Grafika, Jakarta, hlm.23. sebagai bentuk pelaksanaan dalam mewujudkan perbankan yang sehat. ${ }^{5}$

Berasarkan Surat Edaran Meneg. PM dan P.BUMN No. S. 106/M.PM P.BUMN/ 2000, tanggal 17 April 2000 tentang kebijakan penerapan Corporate Governance (selanjutnya disebut CG), CG diartikan sebagai suatu hal yang berkaitan dengan pengambilan keputusan yang efektif yang bersumber dari budaya perusahaan, etika, nilai, sistem, proses bisnis, kebijakan, struktur organisasi perusahaan yang bertujuan untuk mendorong dan mendukung pengembangan perusahaaan, pengelolaan sumber daya dan resiko secara lebih efisien dan efektif, pertanggung jawaban perusahaan kepada pemegang saham dan stakeholders lainnya. PBI menekankan dua aspek penting dari GCG, yaitu: (a) aspek legal; dan (b) aspek perilaku perusahaan. Kendatipun telah ditetapkan pada permualaan tahun 2000 dan kemudian secara khusus diatur dalam PBI sejak tahun 2006, namun azas-azas GCG belum dapat dilaksanakan sebagaimana mestinya. Ketentuan GCG belum dapat mendukung tata kelola perusahaan perbankan sebagaimana diharapkan, terutama dalam hal kinerja pengambilan keputusan. Sebab umum kelemahan itu adalah belum tersedianya sistem informasi hukum (selanjutnya disebut $\mathrm{SIH}$ ) yang memadai yang dapat dipergunakan sebagai dasar untuk menyelenggarakan proses pengambilan keputusan yang cepat dan akurat. Kelambatan dan keraguan dalam pengambilan keputusan pada beberapa bank umumnya sangat ditentukan oleh

Priambodo,R. dan E.Supriyatno, 2007, Penerapan Good Corporate Governance Sebagai Landasan Kinerja Perbankan, Usahawan, Jakarta, hlm.30. 
ketersediaan sistem informasi hukum perusahaan (selanjutnya disebut SIH-P) yang merupakan bank data tentang berbagai kebijakan bank yang telah ditetapkan. Data tentang kebijakan itu mencakup data tentang ragam kebijakan yang telah ditetapkan oleh organ-organ perusahaan, materi kebijakan, dan dasar kebijakan yang telah digunakan sebagai pijakan hukum dalam penetapan suatu kebijakan. ${ }^{6}$

\section{I.2. Rumusan Masalah}

1. Apakah seluruh Bank di Bali telah memiliki Sistem Informasi Hukum Perusahaan dalam rangka pelaksanaan azas akuntabilitas sebagai salah satu azas Good Corporate Governance (GCG)?

2. Bagaimanakah model sistem informasi hukum perusahaan yang digunakan oleh Bank dalam mewujudkan azas akuntabilitas sebagai salah satu azas Good Corporate Governance (GCG)?

\section{I.3. Tujuan Penelitian}

Adapun yang menjadi tujuan dari penelitian ini adalah sebagai berikut :

\section{I.3.1. Tujuan Umum}

Penelitian ini secara umum bertujuan untuk mengembangkan Ilmu Hukum terkait dengan paradigma science as a process (ilmu sebagai proses), dengan paradigma ini ilmu tidak akan pernah mandek (final) dalam penggaliannya atas kebenaran di bidang obyeknya masing-masing. ${ }^{7}$

Leo J. Susilo dan Karlen Simarmata, 2007, Good Corporate Governance Pada Bank, Hikayat Dunia, Jakarta, hlm.4.

7 Program Studi Magister (S2) Ilmu Hukum Program Pasca Sarjana Universitas Udayana, 2013, Pedoman Penulisan Usulan Penelitian Tesis dan Penulisan Tesis Program Studi Magister (S2) Ilmu Hukum, Denpasar, hlm.43.

\section{I.3.2. Tujuan Khusus}

Sedangkan yang menjadi tujuan khusus dari penelitian ini adalah sebagai berikut:

a. Mengkonstruksikan informasi tentang Bank di Bali yang telah memiliki Sistem Informasi Hukum Perusahaan dalam rangka pelaksanaan asas akuntabilitas sebagai salah satu azas $G C G$ dan korelasi informasi itu dengan penyelenggaraan proses kebijakan yang cepat dan akurat pada bank.

b. Mengkonstruksikan model sistem informasi hukum perusahaan yang digunakan oleh Bank dalam rangka mewujudkan azas akuntabilitas sebagai salah satu azas $G C G$ dan korelasi model itu dengan proses pengambilan kebijakan perusahaan yang cepat dan akurat dalam rangka tata kelola bank yang akuntabel dan berdaya saing tinggi.

\section{I.4. Metode Penelitian}

Karya ilmiah ini menggunakan metode penelitian yuridis empiris. Penelitian yuridis empiris terdiri dari 4 komponen, yaitu: (1) penelitian terhadap identifikasi hukum (hukum tidak tertulis); (2) penelitian terhadap efektifitas hukum; (3) penelitian perbandingan hukum; dan (4) penelitian sejarah hukum. ${ }^{8}$ Dalam hal ini, penelitian yang dipergunakan adalah penelitian mengenai efektifitas hukum, yaitu Penyelenggaraan Sistem Informasi Hukum Perusahaan Pada Badan Usaha Bank Dalam Pelaksanaan Good Corporate Governance.

H. Zainuddin Ali M.A., 2010, Metode Penelitian Hukum, Cetakan Kedua, Sinar Grafika, Jakarta, hlm.30-45. 
Adapun sumber data yang digunakan untuk mendukung penulisan karya ilmiah ini didapat dari dua sumber, yaitu :

\section{Sumber Data Primer}

Data primer merupakan data yang diperoleh langsung dari sumber pertama. ${ }^{9}$ Dalamhalini dataprimeryangakandigunakan adalahdenganmelakukanpenelitianlapangan guna mencari data yang akurat. Penelitian ini dilakukan dengan mewawancarai Pimpinan Bank untuk mengetahui apakah pada bank tersebut telah memiliki Sistem Informasi Hukum Perusahaan atau belum memiliki dalam rangka pelaksanaan azas akuntabilitas sebagai salah satu azas $G C G$ yaitu bank milik daerah (BPD Bali kantor Pusat Denpasar), bank BUMN (BNI 46 kantor cabang Gatot Subroto Barat Denpasar), dan bank perkreditan rakyat (BPR Kertawan kantor pusat Gianyar) yang berkedudukan di provinsi Bali yakni Kota Madya Denpasar dan Kabupaten Gianyar dimana kantor pusat bank-bank tersebut berada di wilayah kota Denpasar dan Gianyar yang dimana memiliki tingkat mobilitas perekonomian dan perbankan yang sangat tinggi.

2. Sumber Data Sekunder

Data sekunder yang digunakan adalah dengan melakukan penelitian kepustakaan, yaitu dengan cara mengkaji kembali peraturan yang sudah ada, baik dalam bahan bacaan hukum ataupun dalam dokumendokumen yang memiliki keterkaitan dengan materi dalam penelitian ini serta untuk menyempurnakan data lapangan.

\section{Hasil dan Pembahasan}

\subsection{Penyelenggaraan Sistem Informasi} Hukum Perusahaan Bank Pada Bank Di Bali

Kesadaran hukum adalah tingkat pengetahuan dan pemahaman hukum seseorang dalam konteks kehidupan sosial di mana seseorang hidup dan berperilaku diantara mausia lainnya. Kesadaran hukum menunjuk pada apa yang dilakukan orang, sesuai atau tidak sesuai dengan hukum yang diketahuinya, yang ia lakukan berdasarkan kesadaran akan kebutuhan mereka terhadap kehidupan sosial yang terpola, tertib, stabil, dan sesuai dengan tujuan keberadaan masyarakat itu. Menurut Susan Selby:

...legal consciousness is used to name analytically the understandings and meanings of law circulating in social relations. Legal consciousness refers to what people do as well as say about law. It is understood to be part of a reciprocal process in which the meanings given by individuals to their world become patterned stabilized, and objectified. ${ }^{10}$

Kesadaran hukum menurut Soerjono Soekanto yakni kesadaran hukum sebenarnya merupakan kesadaran atau nila nilai yang terdapat di dalam diri manusia tentang hukum yang diharapkan ada. Yang ditekankan disini adalah nilai-nilai tentang fungsi hukum. ${ }^{11}$

\footnotetext{
- Susan Selby, Legal Conciousness, New Oxford Companion to Law, Oxford University Press. 2008. hlm.1.http://web.mit.edu/ssi/bey/www/pdf/Legal_ conscicousness, diakses tanggal 22 Mei 2015.

11 Soerjono Soekanto, 1982, Kesadaran Hukum Dan Kepatuhan Hukum (Edisi Pertama), CV. Rajawali, Jakarta, hlm.152.
} 


\section{Sudikno Mertokusumo memi- liki pendapat tentang kesadaran} hukum yang menyatakan bahwa kesadaran hukum berarti kesadaran tentang apa yang seharusnya kita lakukan atau perbuat atau yang seharusnya tidak kita lakukan atau perbuat terutama terhadap orang lain. Ini berarti kesadaran akan kewajiban hukum kita masing-masing terhadap orang lain. ${ }^{12}$ Dengan demikian kesadaran hukum adalah pengetahuan hukum yang dimiliki oleh seseorang dan kemampuan orang itu menggunakan pengetahuan yang dimilikinya yang terwujud dalam bentuk perilaku taat atau perilaku yang bersesuaian dengan hukum sebagai pengetahuan yang dimiliki orang itu. Dalam konteks perusahaan, kesadaran hukum organ perusahaan adalah pengetahuan hukum organ perusahaan dan kemampuan organ tersebut berperilaku sesuai dengan pengetahuan hukum yang dimilikinya, baik dalam bentuk ketaatan maupun kesesuaian perilaku organ itu dengan pengetahuan yang dimilikinya. Dengan demikian, kesadaran hukum organ perusahaan terhadap hakekat dan urgensi sistem informasi hukum perusahaan dalam penyelenggaraan perusahaan perbankan berdasarkan prinsip GCGadalahpengetahuan hukum organ perusahaan tentang posisi dan fungsi sistem informasi hukum perusahaan dan kesesuaian perilaku organ perusahaan dengan sistem informasi hukum yang diketahuinya, mencakup: upaya-upaya pengadaannya, pengelolaannya, penggunaannya, pemeliharaan dan pengembangannya

12 Sudikno Mertokusumo, 1981, Meningkatkan Kesadaran Hukum Masyarakat, Cetakan Pertama, Edisi pertama, Liberty, Yogyakarta, hlm.3. dalam proses pengambilan keputusan atau tindakan perusahaan perbankan. Ukuran kesadaran hukum berdasarkan konsep tersebut adalah: (a) tingkat pengetahuan; dan (2) kemampuan organ perusahaan menggunakan pengetahuan hukumnya dalam menyelenggarakan perusahaan. dalam konteks sistem informasi hukum adalah: (1) pengetahuan tentang posisi dan fungsi sistem informasi hukum perusahaan; dan (2) kegiatan pengadaan dan penggunaan sistem informasi hukum dalam penyelenggaraan proses kebijakan perusahaan.

Ketentuan pelaksanaan GCG pada perusahaan perbankan yang diatur secara umum dalam UUP, mencakup: Governace Structure, Governace Process, maupun Governace Outcome. Pengaturan itu tidak terbatas pada kewajiban kepemilikan, Dewan Komisaris, Direksi, dan prinsip kehatihatian yang harus dianut oleh perbankan. ${ }^{13}$ Penerapan prinsip-prinsip GCG tidak terlepas dari ketaatan pengelolaan usaha terhadap sistem manajemen secara benar dan ketaatan terhadap seluruh atauran hukum yang berlaku, baik terhadap aturan hukum yang berupa peraturan perundang-undangan, kebijaksanaan pemerintah, instrumen hukum Bank Indonesia, serta aturan hukum internal perbankan. ${ }^{14}$

Dalam hal kesadaran hukum organ perusahaan terhadap hakekat dan urgensi SIH-P dalam penyelenggaraan perusahaan

13 Mas Achmad Daniri, 2014, Lead By GCG, Gagas Bisnis, Jakarta, hlm.139.

14 Raffles, Penerapan Good Corporate Governance Dalam Kaitannya Dengan Tata Kelola dan Pengembangan Kelembagaan Perbankan, ejurnal: http://online_journal.unja.ac.id/index. php/jih/article/download/67/56, Diakses, 3 maret 2015. 
perbankan berdasarkan prinsip GCG sangat penting untuk diperhatikan karena dengan adanya SIH-P pada perusahaan perbankan diharapkan dapat membantu kinerja dalam pengambilan keputusan agar cepat, tepat, akuntabel.

I Ketut Rasnu, SE, Kepala Divisi Kepatuhan PT. Bank Pembangunan Daerah Bali (BPD Bali) ${ }^{15}$ berpendapat bahwa SIH-P merupakan komponen GCG yang sangat penting dalam penyelenggaraan perusahaan perbankan. SIH-P merupakan komponen proses kebijakan yang bekaitan dengan salah satu prinsip GCG yaitu prinsip pertanggungjawaban perusahaan dimana segalabentuktindakanorganperusahaanharus memenuhi ketentuan peraturan perundangundangan serta melaksanakan tanggung jawab terhadap masyarakat dan lingkungan sesuai dengan ketentuan tersebut sehingga penyelenggaraan usaha perusahaan dapat terpelihara kesinambungan dalam jangka panjang. Pendapat yang sama juga disampaikan oleh Putu Sukani, yang merupakan Staff SPI PT. Bank Perkreditan Rakyat Kertiawan (BPR Kertiawan) ${ }^{16}$ yang berpendapat bahwa keberadaan SIH-P sangat berkaitan dan berpengaruh terhadap proses pengambilan keputusan dalam menjalankan perusahaan dan lebih jauh merupakan komponen yang menentukan kinerja perusahaan perbankan. A.A Ayu Lis Mardiani yang merupakan Manager Compliance Bank BNI 46 cabang Gatot Subroto Barat Denpasar ${ }^{17}$ berpendapat bahwa kesadaran hukum organ perusahaan dalam penyelenggaraan perusahaan perbankan

\footnotetext{
Wawancara 3 Februari 2015.

16 Ibid
}

berdasarkan prinsip GCG sangat berkaitan dengan dimilikinya SIH-P yang berpengaruh dalam kinerja pengambilan keputusan.

Hasilwawancaratersebutmenunjukkan bahwa organ perusahaan perbankan pada ketiga bank itu telah memiliki pengetahuan hukum tentang posisi dan fungsi SIH-P dalam sistem kebijakan perbankan. Namun demikian, pengujian lebih lanjut terhadap indikator kedua kesadaran hukum, yaitu perbuatan pengadaan dan penggunaan SIH$\mathrm{P}$ dalam sistem kebijakan perbankan pada masing-masing bank itu perlu diteliti lebih lanjut.

Masalah akuntabilitas sudah merupakan kebutuhan mendesak dan tidak bisa ditawar lagi. Pada saat ini, masyarakat memerlukan adanya keterbukaan informasi terutama bagi perusahaan yang sudah go public. Para pemegang saham dan stakeholder lainnya memiliki hak untuk mendapatkan informasi yang relevan secara tepat waktu, akurat, seimbang, dan berkesinambungan. ${ }^{18}$

Dengan keberadaan SIH-P pada perusahaan perbankan diharapkan dapat membantu proses pengambilan keputusan yang cepat, akurat, dan valid yang bertujuan untuk meningkatkan coporate value dalam rangkapenerapansalahsatuprinsipGCGyakni prinsip akuntabilitas. Bank BPD Bali belum memiliki SIH-P. SIH-P pada perusahaan ini masih dalam proses penyusunan. PT Bank BPD Bali telah melakukan berbagai kajian dalam rangka pengadaan sistem informasi demikian itu. Bank BPD Bali menyadari bahwa sistem informasi ini sangat diperlukan

\footnotetext{
Wawancara 10 Maret 2015

18 Muh. Arief Effendi, 2009, The Power of Good Corporate Governace, Teori dan Implementasi, Salemba Empat, Jakarta, hlm. 103.
} 
untuk pengambilan keputusan yang lebih cepat, akurat, dan valid, sehingga berbagai pemborosan dari segi biaya dan waktu dapat ditekan atau dikurangi. Pengurangan biaya atau waktu yang tidak diperlukan itu identik dengan efisiensi yang sangat berpengaruh terhadap kinerja (performance) perusahaan. Performance perusahaan merupakan komponen yang mempengaruhi derajat akuntabilitas perusahaan.

BPR Kertiawan berpendapat berbeda. BPR ini berpendapat bahwa mereka belum memerlukan SIH-P dalam rangka pengambilan keputusan. Alasan yang disampaikan berkenaan dengan hal itu adalah bahwa SIH-P tidak dipersyaratkan secara ketentuan hukum. GCG perbankan secara normatif hanya mempersyaratkan akuntabilitas dan tidak menjelaskan atau mempersyaratkan lebih lanjut SIH-P sebagai komponen penting yang menentukan akuntabilitas. Alasan lainnya adalah BPR memiliki skup kerja yang lebih sempit dibanding bank umum yang lebih besar, sehingga keputusan perusahaan cukup diambil berdasarkan sistem informasi hukum manual sebagaimana yang sudah digunakan selama ini.

Pandangan berbeda dari kedua bank itu menunjukkan bahwa pengadaan atau keberadaan SIH-P tidak didasarkan pada kebutuhanhukum,melainkan padakebutuhan praktis perusahaan dalam pengambilan keputusan. Kebutuhan demikian itu dipengaruhi oleh skup kerja dari bank yang bersangkutan. Bank- bank besar dengan skup kerja yang lebih besar dan luas cenderung memerlukan SIH-P dalam pengambilan keputusan untuk menjamin terselenggaranya prinsip akuntabilitas perusahaan. Sedangkan bank yang skup kerjanya kecil tidak terlalu memerlukan SIH-P dalam performa yang khusus, melainkan cukup menggunakan SIH-P manual.

Pertimbangan bank-bank kecil itu tidak dapat dipertahankan karena masalah akuntabilitas bukan hanya masalah perusahaan bank itu sendiri, melainkan juga masalah masyarakat sebagai salah satu pemangku kepentingan dominan pada bank yang memerlukan performa bank yang terbaik dalam rangka melindungi kepentingan mereka secara adil. Sekalipun ketentuan PBI tidak mensyaratkan SIH-P sebagai komponen akuntabilitas perusahaan, namun dalam rangka pengambilan keputusan yang akurat, sistem demikian itu merupakan komponen akuntabilitas yang tidak dapat ditiadakan. Sifat incidental dari masalah atau sengketa juga merupakan pertimbangan lain yang meningkatkan urgensi SIH-P pada setiap perusahaan perbankan. Alasan lainnya adalah efek internal dan eksternal akuntabilitas perusahaan, yaitu efisiensi yang eningkatkan keuntungan dan performa perusahaan yang meningkatkan kepercayaan masyarakat dan lebih jauh daya saing dan keberlanjutan daya hidup perusahaan.

SIH-P merupakan komponen vital proses pengambilan keputusan perusahaan (company decision making process), terutama pengambilan keputusan yang cepat dan tepat (quick and accurate) dalam menghasilkan keputusan yang responsive terhadap perkembangan kebutuhan internal dan eksternal perusahaan. Proses penetapan keputusan yang cepat merupakan bagian dari tampilan perusahaan yang berhubungan erat dengan daya saing perusahaan dengan perusahaan sejenis lainnya. Kelambanan 
proses pengambilan keputusan merupakan sebab utama yang mengakibatkan ketertinggalan perusahaan atau menurunnya daya saing perusahaan atau ketidaktepatan keputusan merupakan sumber masalah yang berhubungan dengan pemborosan waktu dan biaya yang berhubungan erat dengan penghasilan atau keuntungan perusahaan. Keputusan yang tidak tepat merupakan sumber masalah dan masalah merupakan sumber pemborosan yang mempengaruhi efisiensi dan akhirnya penghasilan dan keuntungan perusahaan. Karena itu, SIH$\mathrm{P}$ merupakan komponen vital perusahaan yang menentukan tampilan dan daya saing perusahaan. Untuk keperluan itu, SIH- P merupakan komponen perusahaan yang seharusnya ditata bersamaan dengan penataan organisasi perusahaan dan alur proses keputusan perusahaan.

SIH-P merupakan jabaran visi, misi, tata nilai, lingkup, tujuan dan strategi bisnis perusahaan. Tantangan terberat dalam mengimplementasikan GCG yakni merumuskan dan mengkomunikasikan visi, misi, tata nilai, serta lingkup, tujuan dan strategi bisnis perusahaan. Menejemen perusahaan hendaknya merumuskan tahapan implementasi, tata nilai, etika bisnis, budaya dan tujuan akhir perusahaan yang akan dicapai melalui dedikasi dan keyakinan terhadap manfaat penerapan GCG. Dalam operasional perusahaan, nilai perusahaan serta keuntungan yang dihasilkan tercermin dalam laporan keuangan dan merupakan indikator bahwa apa yang telah dilakukan perusahaan telah sejalan dengan strategi bisnis dan target pencapaian yang disepakati. Namun disadari bahwa angka saja tidak cukup untuk mencerminkan kondisi perusahaan yang sebenarnya. Pada akhirnya, kesuksesan perusahaan justru diukur dari dukungan penuh dari semua organ perusahaan beserta stakeholders, serta SIH-P yang memadai, karena seluruh tampilan sistem dan strategis perusahaan senantiasa diukur dari sistem pengambilan keputusan dan hasilnya yang memadai.

Bagian terpenting dan merupakan soft part di perusahaan adalah tata nilai perusahaan yang pada perusahaanperusahaan besar (corporation) dijabarkan di dalam sistem pengambilan keputusan perusahaan. Diperlukan rumusan atas perilaku yang dapat diterima oleh semua insan perusahaan sebagai faktor utama semua aspek diperusahaan, bagian yang lain yang tak kalah penting adalah akuntabilitas, diperlukan sanksi yang tegas pada individu yang melanggar pedoman perilaku perusahaan agar menjadi contoh bagi yang lain bahwa hal itu tidak dapat ditoleransi oleh perusahaan. Di balik semua itu, belum banyak perusahaan menyadari bahwa sistem pengambilan keputusan yang tertata dengan baik merupakan kunci yang menentukan hasil akhir kinerja perusahaan.

GCG tidak hanya sekedar sistem dan tata nilai, namun mencakup pola hubungan antara manajemen puncak sampai kepada pegawai paling bawah maupun para pemangku kepentingan yang berujung pada konsumen dimana GCG dikomunikasikan dengan efektif dan dipahami oleh semua pihak. Dalam pengelolaan perusahaan kesuksesan bukan semata-mata hanya mengejar keuntungan. Pengelolaan bisnis perusahaan yang dilandasi oleh prinsip GCG selalu memiliki indikator kesuksesan yang diturunkan dari visi, misi, tata nilai dan 
rencana strategis perusahaan jangka panjang yang salah satu bentuknya harus diwujudkan dalam sistem atau alur proses pengambilan keputusan yang cepat dan tepat.

\subsection{Model Sistem Informasi Hukum Perusahaan Yang Digunakan Oleh Bank Dalam Mewujudkan Azas Akuntabilitas Sebagai Salah Satu Azas Good Corporate Governance (GCG)}

SIH diklasifikasi atas 3 (tiga) jenis, yaitu: (a) SIH-P departemental atau sektoral; (b) SIH-P terintegrasi; dan (c) sistem campuran.

SIH-P sektoral adalah SIH-P yang dibangun berdasarkan jenis kegiatan perusahaan dan dibangunan pada setiap departemen yang mengelola urusan perusahaan tertentu. Jika di dalam suatu perusahaan terdapat 5 (lima) departemen, maka pada perusahaan tersebut dibangun 5 (lima) sektor SIH-P. SIH-P terintegrasi adalah SIH-P yang bersifat terpusat. Seluruh SIH-P untuk seluruh departemen di dalam perusahaan itu dikelola oleh satu departemen yangsecarakhususmengelolasistemtersebut. SIH campuran adalah SIH yang dibangun berdasarkan urusan yang dikelola oleh setiap departemen, tetapi di dalam perusahaan itu juga dibangunan suatu departemen khusus yang mengintegrasi seluruh sistem informasi dari setiap departemen.

Setiap departemen disamping bertugas mengembangkan dan mengelola sistem informasi hukumnya sendiri juga bertugas menyediakan atau pelaporkan data hukum dari departemennya kepada departemen yang mengelola urusan sistem sistem informasi hukum. Departemen yang bertugas mengelola urusan informasi hukum bertugas mengintegrasikan data hukum yang disajikan oleh setiap departemen ke dalam SIH-P yang terintegrasi. Pada model campuran, taggungjawab penyimpanan dan pemeliharaan keamanan data yang disimpat, demikian juga penyajiannya didistribusikan secara berimbang pada setiap departemen dan departemen yang secara khusus mengelola urusan pengelolaan informasi hukum perusahaan. Peraturan perusahaan umumnya menentukan alokasi urusan, tugas, kewenangan dan tanggungjawab masingmasing departemen dalam soal itu.

Disisi lain kata sistem dalam hubungannya dengan sistem kearsipan biasanya menunjukkan metode penyusunan atau metode klasifikasi (penggolongan), tetapi dapat juga berarti macam perlengkapan yang dipergunakan, organisasi penyusun tenaga kerja, dan metode-metode yang dipergunakan apabila meminjam dan mengembalikan surat. ${ }^{19}$ Arsip mempunyai peranan penting dalam proses penyajian informasi bagi pimpinan untuk membuat keputusan dan merumuskan kebijakan, oleh sebab itu untuk dapat menyajikan informasi yang lengkap, cepat dan benar haruslah ada sistem dan prosedur kerja yang baik di bidang kearsipan sebagai bukti akuntabilitas kinerja instansi pemerintah maupun swasta. ${ }^{20}$

$$
\text { Pada Pasal } 29 \text { Undang-Undang }
$$
Kearsipan menyebutkan bahwaunit kearsipan pada pencipta arsip dan lembaga kearsipan sebagaimana dimaksud dalam

\footnotetext{
9 Moekijat, 2008, Administrasi Perkiantoran, CV. Mandar Maju, Bandung, hlm.118.

20 Thomas Wiyasa, 2003, Tugas Sekretaris dalam Mengelola Surat dan Arsip Dinamis, Cet.1, Pradnya Paramita, Jakarta, hlm.192.
} 
Pasal 16 ayat (2) harus dipimpin oleh sumber daya manusia yang profesional dan memiliki kompetensi yang diperoleh melalui pendidikan formal dan/atau pendidikan dan pelatihan kearsipan. Dalam hal pengelolaan SIH-P pada perusahaan perbankan sangat dibutuhkan tenaga profesional yang memenihi syarat sebagai seorang arsiparis yang dimana tenaga ahli tersebut harus mengerti tentang hukum dan/atau mengerti tentang produk hukum perusahaan yang dimiliki perusahaan.

Bentuk SIH-P yang digunakan oleh Bank BPD Bali saat ini dalam bentuk Perundang-undangan, PBI dan Keputusan Direksi. Untuk kedepannya, Bank BPD Bali sangat memerlukan SIH-P yang terstruktur, terorganisasi dan lengkap dalam rangka penerapan GCG yang diharapkan bisa meningkatkan daya saing perusahaan. Sedangkan pada BPR Kertiawan belum memilikibentukSIH-Pyang digunakandalam pengambilan keputusan, dan tidak memiliki model SIH-P dalam rangka memenuhi kebutuhan pengambilan keputusan yang cepat. Pada Bank BNI pedoman pengambilan keputusan dengan mengacu pada Pedoman Perusahaan Online atau EPP (elektronik pedoman perusashaan), maka dengan adanya SIH-P yang terstruktur dan lengkap sangat diperlukan dalam pengambilan keputusan agar keputusan yang diambil lebih cepat dan akurat.

SIH-P pada perusahaan perbankan di Bali dilaksanakan dengan berbagai cara. Bentuk pelaksanaan ini setidaknya dapat dikualifikasikan atas dua bentuk, yaitu Manual dan Sistem komputer sederhana.

Sistem manual adalah sistem yang tersusun secara manual dengan menggunakan model pengarsipan manual. Sistem komputer sederhana adalah SIH-P yang disusun dengan menggunakan perlengkapan komputer sebagai peralatan, namun belum menggunakan model sistem tertentu. Kedua sistem ini pada dasarnya tidak jauh berbeda dari segi sistem perekaman dan sistem penyajian informasi. Perbedaannya hanya terletak dari segi peralatan yang digunakan.

Bentuk SIH-P yang digunakan oleh Bank BPD Bali saat ini dalam bentuk Perundang-undangan, PBI dan Keputusan Direksi. Untuk kedepannya, Bank BPD Bali sangat memerlukan SIH-P yang terstruktur, terorganisasi dan lengkap dalam rangka penerapan GCG yang diharapkan bisa meningkatkan daya saing perusahaan. Sedangkan pada BPR Kertiawan belum memiliki bentuk SIH-P yang digunakan dalam pengambilan keputusan, dan tidak memiliki model SIH-P dalam rangka memenuhi kebutuhan pengambilan keputusan yang cepat. Pada Bank BNI 46 pedoman pengambilan keputusan dengan mengacu pada Pedoman Perusahaan Online atau EPP (elektronik pedoman perusashaan), maka dengan adanya SIH-P yang terstruktur dan lengkap sangat diperlukan dalam pengambilan keputusan agar keputusan yang diambil lebih cepat dan akurat.

Dari data lapangan yang ditemukan model pelaksanaan SIH-P pada umumnya hanya sebatas kepemilikan standar operasional prosedur(SOP)danmerujuk pada undang-undang terkait pelaksaaan GCG dalam penyelenggaraan sistem informasi pada perusahaan perbankan yang ada. Masih kurangnya tenaga profesional yeng memenuhi syarat sebagai seorang arsiparis yang dapat mengelola SIH pada perusahaan 
perbankan yang berakibat tidak dimilikinya $\mathrm{SIH}-\mathrm{P}$ dalam menunjang performance perusahaan dalam penyelenggaraan GCG. Penyelenggaraan GCG dapat dikatakan sebagai suatu penilaian yang obyektif dalam menilai suatu perusahaan perbankan telah memiliki SIH-P yang terintergasi menunjang pengambilan keputusan perusahaan agar cepat, tepat, dan akurat dengan tujuan peningkatan corporate value.

Model SIH-P yang ideal bagi perusahaan perbankan yakni model SIH yang berbasis komputerisasi sederhana yang dikelola seorang yang arsiparis yang berpendidikan minimal strata satu (S1) ilmu hukum yang mengerti tentang produk hukum perusahaan yang dimiliki perusahaan perbankan tersebut. Dengan adanya model SIH-P yang berbasis komputerisasi sederhana diharapkan dapat membantudalam pengambilan keputusan yang cepat, tepat, dan akurat sebagai bentuk implementasi GCG pada perusahaan perbankan. Dengan SIH-P yang berbasis komputerisasi yang nantinya dapat diakses oleh stakeholders dalam rangka penyelenggaraan perusahaan yang akuntabel dan berdaya saing tinggi.

Sedangkan Model SIH-P yang ada pada saat ini Bank BPD Bali dalam bentuk Surat Edaran Bank Indonesia dan bentuk Keputusan Direksi. Model SIH$\mathrm{P}$ yang diharapkan oleh Bank BPD Bali yakni yang bias diakses oleh setiap kantor operasional yang ada di Bank BPD Bali sehingga nantinya dengan mudah dapat dipahami dan dilaksanakan di semua lini operasinal. Sedangkan pada BPR Kertiawan berpendapat belum memerlukan adanya SIH-P dalam rangka proses pengambilan keputusan yang cepat dan akurat, dan tidak memiliki model untuk SIH-P dalam rangka pelaksanakan GCG. Model SIH-P yang telah dimiliki oleh Bank BNI 46 dalam rangka pengambilan keputusan yang cepat dan akurat telah memenuhi dan telah sesuai dengan kebutuhan perusahaan. Sedangkan model SIH- P yang diperlukan yakni sistem yang memuat kumpulan peraturan yang sejalan dengan perkembangan bisnis lengkap dengan mitigasi resikonya. Dari data yang diperoleh dilapangan menunjukkan bahwa belum adanya model SIH-P yang ideal dimiliki oleh perusahaan perbankan dibali. Masih sedikit yang mengetahui bahwa pentingnya SIH yang dimiliki tersebut sangat mempengaruhi daya saing perusahaan dalam rangka penyelenggaraan GCG. adanya SIH$P$ yang ideal nantinya dapat membantu organ perusahaan dalam mengambil keputusan tanpa mengurangi resiko kedepannya yang dapat mempengaruhi citra perusahaan.

\section{Simpulan dan Saran}

\subsection{Simpulan}

Berdasarkan uraian- uraian tersebut di atas dapat ditarik kesimpulan sebagai berikut:

1. Perusahaan perbankan di Bali belum seluruhnya memiliki SIH$\mathrm{P}$ dalam rangka pelaksanaan azas akuntabilitas sebagai salah satu azas GCG. Perlunya perusahaan perbankan untuk memiliki SIH-P bertujuan membantu organ perusahaan dalam pengambilan keputusan. SIH-P merupakan komponen vital proses pengambilan keputusan perusahaan (company decision making process), terutama pengambilan keputusan yang cepat dan tepat (quick and accurate) 
dalam menghasilkan keputusan yang responsive terhadap perkembangan kebutuhan internal dan eksternal perusahaan. Untuk keperluan itu, SIH$\mathrm{P}$ merupakan komponen perusahaan yang seharusnya ditata bersamaan dengan penataan organisasi perusahaan dan alur proses keputusan perusahaan. Kekosongan SIH perbankan dapat berimplikasiterhadap penyelenggaraan sistem pengelolaan perusahaan, sistem pengambilan keputusan, dan sistem penyelenggaraan usaha perusahaan.

2. Model SIH-P yang digunakan oleh Bank dalam mewujudkan azas akuntabilitasyaknisebataskepemilikan standar operasional prosedur (SOP) dan merujuk pada undang-undang terkait pelaksaaan $G C G$ dalam penyelenggaraan sistem informasi pada perusahaan perbankan yang ada. Masih kurangnya tenaga profesional yeng memenuhi syarat sebagai seorang arsiparis yang dapat mengelola SIH pada perusahaan perbankan yang berakibat tidak dimilikinya SIH$\mathrm{P}$ dalam menunjang performance perusahaan dalam penyelenggaraan $G C G$ Masih sedikit yang mengetahui bahwa pentingnya SIH yang dimiliki tersebut sangat mempengaruhi daya saing perusahaan dalam rangka penyelenggaraan GCG. Adanya SIH$P$ yang ideal nantinya dapat membantu organ perusahaan dalam mengambil keputusan tanpa mengurangi resiko kedepannya yang dapat mempengaruhi citra perusahaan.

\subsection{Saran}

1. Diharapkan kedepannya agar pemerintah khususnya Bank Indonesia membuat regulasi yang tegas mengatur tentang standarisasi model kepemilikan SIH-P pada perusahaan perbankan agar tidak ada ketimpangan antara penyelenggaraan GCG dengan aturan yang mengatur didalamnya. SIH-P sangat membantu para pelaku usaha perbankan khususnya untuk menilai kinerja pelaksanaan GCG pada perusahaan agar citra perusahaan dapat ditingkatkan kearah yang lebih baik.

2. Dengan terciptanya SIH-P diharapkan pelaku usaha perbankan melaksanakannya dengan baik dan mencetak profesional muda yang memiliki latar belakang pendidikan sebagai seorang sarjana hukum untuk dapat mengelola SIH-P tersebut agar dapat berjalan dengan baik. 


\section{DAFTAR PUSTAKA}

Hendrik Budi Untung, 2008, Corporate Social Responsibility, Sinar Grafika, Jakarta.

Hendrik Budi Untung, 2008 Corporate Social Responsibility, Sinar Grafika, Jakarta.

H. Zainuddin Ali M.A., 2010, Metode Penelitian Hukum, Cetakan Kedua, Sinar Grafika, Jakarta.

Leo J. Susilo dan Karlen Simarmata, 2007 Good Corporate Governance Pada Bank, Hikayat Dunia, Jakarta.

Mas Achmad Daniri, 2014, Lead By GCG, Gagas Bisnis, Jakarta.

Muh. Arief Effendi, 2009, The Power of Good Corporate Governace, Teori dan Implementasi, Salemba Empat, Jakarta.

Moekijat, 2008, Administrasi Perkiantoran, CV. Mandar Maju, Bandung.

Neni Sri Imaniyanti, 2010, Pengantar Hukum Perbankan Indonesia, Refika Aditama, Bandung.

Priambodo. R. dan E.Supriyatno, 2007, Penerapan Good Corporate GovernanceSebagaiLandasan Kinerja Perbankan, Usahawan, Jakarta.

Program Studi Magister (S2) Ilmu Hukum Program Pasca Sarjana UniversitasUdayana, 2013, Pedoman Penulisan Usulan Penelitian Tesis dan Penulisan Tesis Program Studi Magister (S2) Ilmu Hukum, Denpasar.

Raffles, Penerapan Good Corporate Governance Dalam Kaitannya Dengan Tata Kelola dan Pengembangan Kelembagaan Perbankan, e jurnal: 20http://online journal. unja.ac.id/index.php/ jih /article/ download/67/56.

Redo Harina Hutama, 2013, Good Corporate Governance Sebagai Salah Satu Faktor Penilaian Tingkat Kesehatan Bank Umum, Private Law: Vol. 03 Nov 2013 - Maret 2014. No. 23., Surakarta.

Soerjono Soekanto, 1982, Kesadaran Hukum Dan Kepatuhan Hukum (Edisi Pertama), CV. Rajawali, Jakarta.

Sudikno Mertokusumo, 1981, Meningkatkan Kesadaran Hukum Masyarakat, Cetakan Pertama, Edisi Pertama, Liberty, Yogyakarta.

Susan Selby, Legal Conciousness New Oxford Companion to Law 6Oxford University Press. 2008,http://web. mit.edu/ssilbey/www/pdf/Legal consciousness.

Thomas Wiyasa, 192003, Tugas Sekretaris dalam Mengelola Surat dan Arsip Dinamis, Cet.1, Pradnya Paramita, Jakarta. 